DEVELOPMENT OF BIOLOGICAL COAL GASIFICATION (MICGAS PROCESS)

$\mathrm{DOE} / \mathrm{MC} / 27226--3192$

8th Quarterly Report

DE93 006361

DOE-METC Contract NO. DE-AC21-90MC27226

\author{
Submitted to: \\ Department of Energy \\ Morgantown Energy Technology Center \\ P.O. Box 880 \\ 3610 Collins Ferry Road \\ Morgantown, WV 26507-0880
}

July 28, 1992

Subritted by:

ARCTECH, InC. 14100 Park Meadow Dr. Chantilly, VA 22021

\title{
DISCLAIMER
}

This report was prepared as an account of work sponsored by an agency of the United States Government. Neither the United States Government nor any agency thereof, nor any of their employees, makes any warranty, express or impliod, or assumes any legal liability or responsibility for the accuracy, completeness, or usefulness of any information, apparatus, product, or process disclosed, or represents that its use would not infringe privately owned rights. Reference herein to any specific commercial product, process, or service by trade name, trademark, manufacturer, or otherwise does not necessarily constitute or imply its endorsement, recommendation, or favoring by the United States Government or any agency thereof. The views and opinions of authors expressed herein do not necessarily state or reflect those of the United States Government or any agency thereof. 


\section{DEVELOPMENT OF BIOLOGICAL COAL GASIFICATION (MicGAS PROCESS)}

Tasks 1 and 2:

These tasks have been completed.

Task 3 - Coal-Microbial Interactions:

Subtasks $3.1-3.2$

These subtasks have been completed.

\section{Subtask 3.3 - Solids Loadings}

Laboratory scale studies examining biogasification of Texas lignite at various coal solids loadings have been completed. The results of these studies were presented in the 6 th quarterly report. Experiments designed to scale up the biogasification process to higher solids loadings ( $10 \%$ and higher) are in progress using bench scale bioreactors.

Task 4 - Biological Production of Methane from Coal: Optimization of the Process:

\section{Subtask 4.1 - Selection of co-substrates}

An experiment determining the minimum concentration of Sheftone $T$ required for biogasification has been completed. Bottles containing new termite medium (with and without Texas lignite; $0.1 \% \mathrm{w} / \mathrm{v},-325 \mathrm{mesh}$ ) were inoculated with active Mic-1 culture. Sheftone $\mathrm{T}$ at $0.2 \%, 0.1 \%$ and $0.05 \%(\mathrm{w} / \mathrm{v})$ concentrations was ased in place of yeast extract and tryptic soy broth (YE/TSB). In addition, bottles with $\mathrm{YE} / \mathrm{TSB}$ at $0.2 \% \mathrm{w} / \mathrm{V}$ were used as positive controls. Total gas, methane and carbon dioxide production were monitored weekly.

The highest methane production of $110 \mathrm{cc} / \mathrm{gram}$ of coal was observed after 21 days in reactions containing $0.2 \%$ sheftone $T$. This was $42 \%$ greater than the methane production in reactions containing $0.2 \% \mathrm{YE} / \mathrm{TSB}(64 \mathrm{cc} / \mathrm{gram}$ of coal). Maximum methane production was attained at 7 days in reactions containing $0.1 \%$ and $0.05 \%$ Sheftone $T$ ( 39 and $15 \mathrm{cc} /$ gram of coal, respectively). After 7 days, methane production decreased in these reactions. The results of this study indicate that sheftone $T$ at $c .2 \% \mathrm{w} / \mathrm{v}$ could replace $\mathrm{YE} / \mathrm{TSB}$ in biogasification experiments without reducing the rate of conversion of coal so methane.

studies examining the use of sheftone $T$ as a nutrient amendment have been performed using Texas lignite at $0.1 \% \mathrm{w} / \mathrm{V}$. An 
experiment was performed to compare YE/TSB with sheftone $T$ using $1.0 \%$ Texas lignite and MiC-1. In addition to YE/TSB and sheftone $T$, three additional amendments (corn steep liquor, dried blood and solubilized sewage sludge) were also tested. All amendments were used at $0.2 \%$. As in previous studies, reactions containing Sheftone $T$ produced more methane than those containing YE/TSB. Reactions with corn steep liquor or solubilized sewage sludge produced very little methane. The reactions containing dried blood produced more methane than those with YE/TSB. However, methane production was less than that observed in the presence of Sheftone T.

In current biogasification medium formulations, a solution of B-vitamins is added. It is possible that sheftone $T$ alone will provide sufficient vitamins for biogasification. An experiment is underway to sxamine this. New termite medium (with $0.2 \%$ Sheftone T) was prepared without vitamin solution and dispensed into bottles with and without Texas lignite (0.1\% w/v final solids loadings). The appropriate volume of B-vitamin solution was added to half of the bottles. The bottles were inoculated with Mic-1 culture which had been centrifuged and resuspended in vitamin-free medium. Total gas, methane and carbon dioxide production are being monitored at periodic intervals. The results of this study will indicate whether B-vitamin solution can be omitted from the reaction medium without inhibiting methane production. This will help to further reduce the cost of the MicGAS process.

\section{Subtask 4.2 - Isolation and Characterization of Bacteria}

Experiments performed earlier indicated that none of the 13 pure isolates obtained from the MiC-1 and Mic-4 biogasification consortia are primary coal degraders. To determine whether these cultures are hydrocarbon degraders/acetogens, samples of the liquid phase were taken from cultures of the pure isolates and analyzed for volatile fatty acids (VFAs). The results of these analyses are presented in Table 1.

With the exception of M4-2 and M4-8, each isolate produced acetate at a concentration greater than $100 \mathrm{ppm}$. The greatest concentration if acetate was produced by M4-1 (404 ppm), an isolate from Mic-4. The greatest concentration of acetate produced by an isolate from Mic-1 was $298 \mathrm{ppm}$, produced by MI-2. Several other VFAs were produced in smaller quantities by the various isolates. Based on these data, it is concluded that the bacteria isolated to date are primarily acetogens. It is interesting to note that four isolates (M1-4, M4-2, M4-4 and M4-8) produced detectable amounts of ethanol.

It is likely that some of the isolates are actually the same bacterial species. Certain isolates produced similar amounts of the same VFAs. Based on comparisons of the production of various VFAs, as well as other characteristics (eg. cell morphology, Gram stain, etc.), it appears that the 13 isolates represent seven 
Table 1. Volatile vtty acid (VFA) concentrations in cultures of pure isolates obtained from MiC-1 and Mic-4 grown in new termite medium with $0.1 \%$ Texas lignite.

VFA $(p p m)^{a}$

$\begin{array}{lccccc}\text { Isolate }^{\text {Acet }} & \text { Prop } & \text { Buty } & \text { EtOH } & \text { Others } \\ \text { M1-1 } & 268 & 99 & 78 & \text { ND } & 204 \\ \text { M1-2 } & 298 & 32 & \text { ND } & \text { ND } & 149 \\ \text { M1-3 } & 291 & 96 & 73 & \text { ND } & 211 \\ \text { M1-4 } & 166 & \text { ND } & 88 & 29 & 179 \\ \text { M1-5 } & 293 & 92 & 76 & \text { ND } & 213 \\ \text { M4-1 } & 404 & 55 & \text { ND } & \text { ND } & 195 \\ \text { M4-2 } & 58 & \text { ND } & 22 & 27 & \text { ND } \\ \text { M4-3 } & 258 & 120 & \text { ND } & \text { ND } & 197 \\ \text { M4-4 } & 176 & \text { ND } & 84 & 46 & 152 \\ \text { M4-5 } & 357 & 38 & \text { ND } & \text { ND } & 173 \\ \text { M4-6 } & 272 & 93 & 87 & \text { ND } & 215 \\ \text { M4-7 } & 129 & 36 & 104 & \text { ND } & \text { ND } \\ \text { M4-8 } & 64 & \text { ND } & 24 & 31 & \text { ND }\end{array}$

- Acet $=$ Acetic, Prop = Propionic, Buty = Butyric, EtoH = Ethanol, athers = Isobutyric, Isovaleric, Isocaproic.

- 14 days of incubation.

- ND = Non-detectable levels. 
different bacterial species. Although more comprehensive testing is required to confirm this, for the purpose of this project they will be considered as seven distinct bacterial species. Table 2 lists the isolates according to their common groupings.

Efforts to isolate primary coal degrading bacteria are continuing. It is possible that the primary coal degrading bacteria can only grow and degrade ccal synergistically, i.e. in the presence of one or more bacterial species. Therefore, mixed sub-populations, rather than pure isolates, are being obtained and studied to determine if they can degrade Texas lignite to methane precursors.

Subtasks $4.3-4.4$

No work was scheduled for these subtasks.

Subtask 4.5 - Bioreactor Studies

In a study by Fluor Daniels, it was pointed out that in order for the MicGAS process to be commercially feasible, it will be necessary to use solids loadings of $20 \%$ or greater. In previous studies, biogasification of Texas lignite at $1 \%$ and $5 \%(\mathrm{w} / \mathrm{v})$ was demonstrated using a rotating biological contactor ( $R B C$ ). In order to further increase coal solids loadings, an RBC reactor has been set up with a coal solids loading of $10 \%(w / v)$. This reactor is currently being run in batch mode.

Irioculum for this reactor consisted of $10 \%(\mathrm{v} / \mathrm{V})$ sewage sludge culture, $6 \% \mathrm{MiC}-4$ and $4 \% \mathrm{Mic}-1$ (total inoculum was $20 \% \mathrm{~V} / \mathrm{V}$ ). Production of total gas, methane and carbon dioxide are being monitored. Volatile fatty acids (VFA) concentrations, soluble carbon (as determined by chemical oxygen demand assay) and cellular protein concentrations in the liquid phase are also-being monitored. Residual coal analysis (carbon and ash) will be performed to determine the changes in coal composition.

After one month of incubation, 6.91 of total gas has been produced. The methane concentration of the headspace gas reached a maximum of 48.4 molez by day 3 , but decreased to 41.0 molez by the end of one month. There was no significant change in the soluble carbon in the liquid phase during this time. Results of the volatile fatty acids and protein analyses are not available at this time.

Two upflow reactors were set up with $700 \mathrm{ml}$ medium (new termite medium with $0.2 \%$ Sheftone $\mathrm{T}$ ) and $100 \mathrm{~g}$ of Texas lignite. A third reactor was prepared without coal to serve as control. Each of the reactors were inoculated with $100 \mathrm{ml}$ sewage sludge culture, $60 \mathrm{mI} \mathrm{MiC-4}$ and $40 \mathrm{ml} \mathrm{Mic-1}$ (total inoculum was $20 \% \mathrm{v} / \mathrm{v}$ ). The final volume was 11 , with a coal solids loadings of $10 \%(\mathrm{w} / \mathrm{v})$. After 5 days, circulation of the headspace gas through the bottom 
Table 2. Bacterial isolates from Mic-1 and Mic-4 grouped as distinct species.

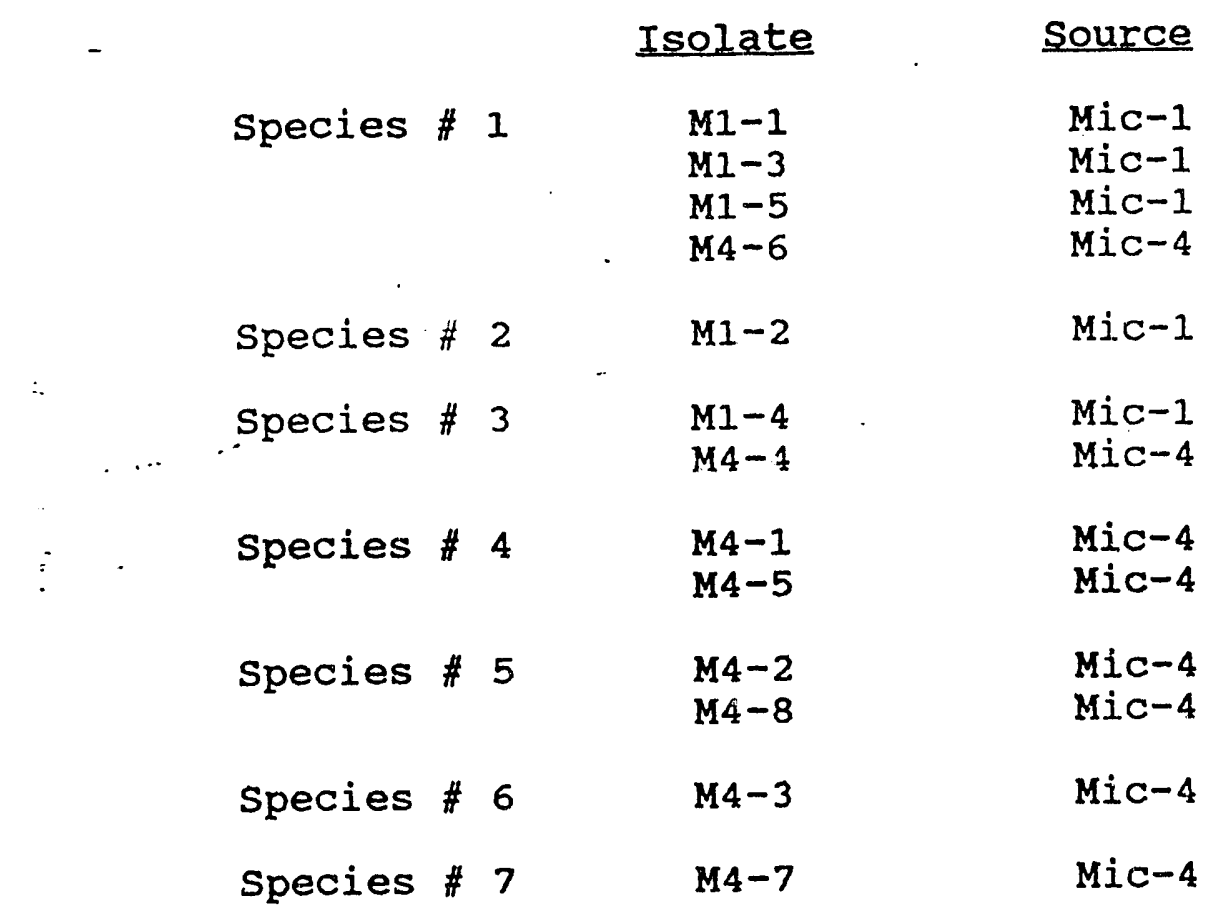


of the reactor was initiated. This was done to facilitate mixing of the coal with the liquid phase. Total gas, methane, and carbor: dioxide production were monitored over time. In addition, volatile fatty acids concentrations, soluble carbon, and cellular protein concentrations in the liquid phase were also monitored.

Initially, significant methane production was observed in all three reactors. Methane concentrations of 48-50 mole\% were present in the headspace gas after four days of incubation. However, gas production decreased rapidly after this time. It is hypothesized that the circulated headspace gas was not able to adequately mix the large mass of coal. This was further evidenced by the fact that one of the reactors containing coal had to be discontinued because the lower circulation port became clogged with coal. The two remaining reactors are still in operation.

Cọnclusions:

In summary:

- The optimum concentration of sheftone $T$ in the biogasification medium is $0.2 \% \mathrm{w} / \mathrm{v}$.

- The bacterial isolates obtained from Mic-1 and Mic-4 are primarily acetogens as indicated by VFA analysis.

- Thirteen pure isolates currently on hand represent seven distinct bacterial species.

Future 'Work:

- Confirm the need for additional B-vitamins in the biogasification medium.

Isolate coal degrading sub-populations from Mic-1 and Mic-4 consortia.

Scale-up of the biogasification process to high solids loadings.

- Evaluation of various bioreactor designs using high coal solids loadings. 

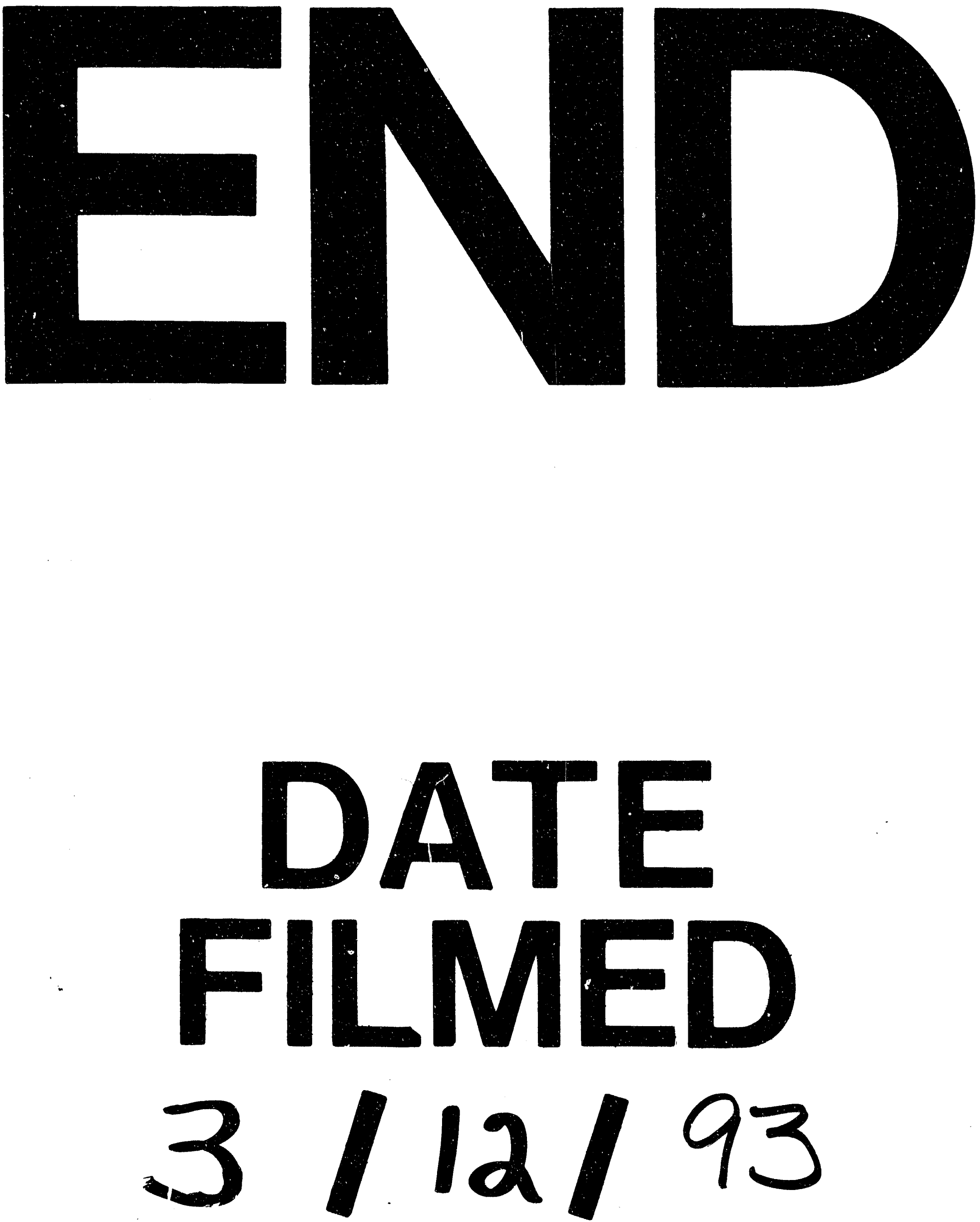
